\title{
KEY TRENDS AND PROBLEMS OF REGIONAL INNOVATION SYSTEMS' DEVELOPMENT IN POLAND AND UKRAINE
}

\author{
Fedirko, 0.
}

This article is devoted to comparative study of regional innovation development in Poland and Ukraine. Innovation potential and performance of Ukrainian regions assessment is grounded on the regional innovation systems approach, employing selected indicators of the EU regional innovation evaluation criteria. Key trends and problematic issues of regional innovation development are captured through a number of methods: comparative analysis, calculating variation of regional innovation capacity indicators within countries and their correlation versus per capita GDP of regions in Poland and Ukraine. The overall low level of R\&D and innovation expenditure, high variation of regional innovation performance, insufficient effects of innovations on the regional GDP dynamics as well as lack of feasible policy instruments to support innovations constitute the main risks for the regional innovation systems considered. Weak and patchy regional innovation performance in both countries fosters import dependent managerial practices driven by foreign technology adoption.

JEL classification: 031

Keywords: regional innovation system; innovation inputs; innovation outputs; variation of regional innovation performance; innovation drivers of regional economic growth

\section{Introduction}

Issues of regional innovation development have beco- me rather popular recently. This could be explained by a number of reasons. First of all, the high level of research potential localization even in leading countries is nowadays a norm rather than an exception: $48 \%$ of the research potential of France is concentrated in the Il de France region, $41 \%$ of the innovation potential of the UK is concentrated in the proximity of London, 33\% of the Italian scientific potential is localized within the Lombardy region (Koschatzky, 2000, p. 16). This trend caused an increased scientific interest to the study of the factors of regional innovation success, such as geographical proximity, agglomeration effects, the availability of innovation infrastructure, local scientific potential, etc. Second, the high level of regional differentiation of innovative capacity required the elaboration of efficient regional policies facilitating local innovative development, employment and convergence. Third, the problems of smart and innovative development were put at the core of the EU strategic document 'Europe 2020'. Accounting for this, EU regional and local development policies obtained a strong innovation focus in the new planning period (2014-2020).
Poland and Ukraine have a common socialist legacy as well as a long history of bilateral economic relations. The basic hypothesis is:

H1: Although Poland and Ukraine have always been strategic economic partners, and at the beginning of 1990s had equal 'starting conditions' for their independent development, the present-day regional innovation systems' (RIS) performance and trajectories differ in the two countries.

This paper is devoted to the analysis of basic trends and problems of regional innovative development in Poland and Ukraine. In view of the ever-growing popularity of the European integration vector of external policy in Ukraine, it is crucially important that its regional innovative performance be assessed against the European statistical and regulatory standards. Thus a comparative analysis of regional innovative potential and innovation outputs has been performed. The aim of this study is to uncover the urgent issues of regional innovation development in the post-soviet states (Ukraine and Poland as examples), and to contribute to the understanding of weak RIS's and their managerial implications. 
The methodology of this paper and the author's vision of the regional innovation development problems build on the innovation systems approach (Freeman, 1987; Nelson, 1992; Lundvall, 1992; Cooke, 1992; Braczyk, Cooke, and Heidenreich, 1998), as well as the Triple Helix model, developed by Etzkowitz and Leydesdorff (1997).

According to Asheim, Lawton-Smith and Oughton (2011, p. 878) "at the core of the RIS approach is an emphasis on economic and social interactions between agents, spanning the public and private sectors to engender and diffuse innovation within regions embedded in wider national and global systems."

\section{Methods}

The methodology for empirical evaluation of regional innovation performance has been elaborated under the coordination of the European Commission in 2002 (European Commission 2012b, p. 8), from then on it has been constantly improved (European Commission, 2012a) to include more indicators of regional innovation. Building on the abovementioned methodologies, as well as the one employed in a recent Polish study (Boguszewski et al., 2013), this research has been elaborated to overcome the weaknesses of regional innovation studies in Ukraine. Special attention is paid to the comparison of regional innovation statistical indicators in Poland and Ukraine. The core technical problem, however, is connected with the lack of most statistical indicators in Ukraine necessary for the complex assessment of regional innovation capacity in full accordance to the EU methodology. Thus the major existing comparable indicators for the Ukrainian regions have been selected and adopted for comparative analysis with Poland and the EU. For example, there's no available equivalent for the EU indicator 'Employment in science and technology', instead another proxy is used - 'Employment in R\&D organizations', which is also available in Polish national statistics. Also, there's no available sector structure of innovation expenditure on the regional level, data on R\&D expenditures in the field of engineering and technology is also missing for Ukrainian regions. However, some positive shifts in the national statistical methodology allowed comparing the share of companies innovating in cooperation, which became available due to a special study conducted by National Statistical Service of Ukraine in 2008-2010 (State Statistical Service of Ukraine, 2012, p. 226).

The selection process led to the final structure of indicators, which had been divided into the two groups: 'innovation inputs' and 'innovation outputs'. The first group includes: the share of gross expenditure on R\&D in the GDP of region (the core indicator reflecting R\&D potential of a region); per capita innovation expenditure (indicator of business financial inputs into innovation activities); the share of companies innovating in cooperation (a good measure of innovation networking and business collaboration); R\&D employment (a measure of human inputs to the innovation process). The effects (outputs) of regional innovation activities are represented by the share of sales of innovative products, the share of companies, introducing innovative products and processes, as well as the number of patents on inventions per million population. The abovementioned indicators are used not only for the direct cross-country comparisons, but also for the evaluation of domestic regional innovation convergence, as well as for capturing the interrelations between innovation potential and performance on the one side, and overall economic development of a region on the other one.

\section{Results}

Table 1 presents comparable regional innovation input' indicators for the two countries. Regional R\&D expenditure as a share of GDP in the Kharkiv region, the cities of Kiev and Sevastopol (Ukraine) appeared to be higher than that of the leading Polish region - Mazovian voivodeship. This conclusion, however, should be treated with caution as Warsaw's indicators after the administrative reform are not reported separately; instead they are included into the amount of Mozavian voivodeship in the official Polish statistics. At the same time, three of the Ukrainian regions reported negligible amounts of R\&D expenditure (Khmelnitskyi, Rivne and Zhytomyr) even less than the lowest level in Poland (Lubusz voivodeship). 


\section{Table 1 Innovation input indicators of Polish and Ukrainian regions}

\begin{tabular}{|c|c|c|c|c|}
\hline Names of regions & $\begin{array}{l}\text { Share of R\&D expen- } \\
\text { diture in the GDP } \\
\text { of region, } \%^{a)}\end{array}$ & $\begin{array}{l}\text { Per capita innovation } \\
\text { expenditure, EUR }\end{array}$ & $\begin{array}{l}\text { Share of companies } \\
\text { innovating in } \\
\text { cooperation, } \% \text { c) }\end{array}$ & $\begin{array}{c}\text { R\&D employment } \\
\text { per } 100 \\
\text { thousand }^{\text {d) }}\end{array}$ \\
\hline ARC (UA) & 0,46 & 9,4 & 2,7 & 136 \\
\hline Cherkasy (UA) & 0,25 & 2,5 & 1,0 & 100 \\
\hline Chernihiv (UA) & 0,20 & 19,8 & 1,2 & 58 \\
\hline Chernivtsi (UA) & 0,36 & 4,5 & 2,6 & 97 \\
\hline Dnipropetrovsk (UA) & 0,63 & 32,1 & 1,8 & 325 \\
\hline Donetsk (UA) & 0,42 & 37,4 & 3,0 & 183 \\
\hline Ivano-Frankivsk (UA) & 0,30 & 74,4 & 0,2 & 70 \\
\hline Kharkiv (UA) & 2,48 & 15,2 & 4,2 & 794 \\
\hline Kherson (UA) & 0,26 & 7,1 & 1,3 & 79 \\
\hline Khmelnytsky (UA) & 0,03 & 48,6 & 2,6 & 8 \\
\hline Kiev city (UA) & 1,91 & 51,3 & 1,4 & 1959 \\
\hline Kiev region (UA) & 0,52 & 8,5 & 2,6 & 171 \\
\hline Kirovohrad (UA) & 0,19 & 6,6 & 1,7 & 48 \\
\hline Luhansk (UA) & 0,27 & 45,2 & 3,6 & 86 \\
\hline Lviv (UA) & 0,70 & 9,3 & 2,1 & 222 \\
\hline Mykolaiv (UA) & 0,96 & 37,2 & 3,1 & 231 \\
\hline Odessa (UA) & 0,35 & 9,4 & 0,2 & 162 \\
\hline Poltava (UA) & 0,13 & 10,5 & 2,3 & 81 \\
\hline Rivne (UA) & 0,08 & 9,1 & 2,2 & 24 \\
\hline Sevastopol city (UA) & 1,43 & 0,9 & 0,8 & 424 \\
\hline Sumy (UA) & 0,56 & 11,4 & 2,9 & 234 \\
\hline Ternopil (UA) & 0,12 & 4,1 & 2,8 & 31 \\
\hline Transcarpathian (UA) & 0,17 & 3,3 & 1,1 & 65 \\
\hline Vinnytsia (UA) & 0,24 & 11,5 & 4,0 & 58 \\
\hline Volyn (UA) & 0,14 & 25,9 & 0,8 & 31 \\
\hline Zaporizhia (UA) & 1,03 & 9,8 & 0,7 & 302 \\
\hline Zhytomyr (UA) & 0,10 & 3,4 & 5,8 & 29 \\
\hline Greater Poland (PL) & 0,52 & 46,6 & 4,9 & 170 \\
\hline Kuyavian-Pomeranian (PL) & 0,22 & 26,3 & 5,2 & 128 \\
\hline Lesser Poland (PL) & 0,95 & 21,2 & 6,8 & 219 \\
\hline Łódź (PL) & 0,54 & 38,6 & 5,1 & 176 \\
\hline Lower Silesian (PL) & 0,44 & 22,2 & 7,9 & 210 \\
\hline Lublin (PL) & 0,48 & 13,3 & 7,1 & 143 \\
\hline Lubusz (PL) & 0,10 & 19,4 & 3,9 & 65 \\
\hline Masovian (PL) & 1,21 & 432,6 & 6,2 & 467 \\
\hline Opole (PL) & 0,14 & 15,0 & 6,0 & 90 \\
\hline Podlaskie (PL) & 0,26 & 3,0 & 5,6 & 131 \\
\hline Pomeranian (PL) & 0,57 & 44,5 & 5,3 & 190 \\
\hline Silesian (PL) & 0,36 & 24,3 & 9,2 & 150 \\
\hline Subcarpathian (PL) & 0,37 & 14,6 & 7,5 & 76 \\
\hline Świętokrzyskie (PL) & 0,27 & 3,7 & 6,7 & 87 \\
\hline Warmian-Masurian (PL) & 0,23 & 4,6 & 6,8 & 86 \\
\hline West Pomeranian (PL) & 0,24 & 12,0 & 5,1 & 100 \\
\hline
\end{tabular}

Notes: a) 2010 data for Ukraine, 2008 data for Poland; b) average 2008-2010 data for Ukraine, 2008 data for manufacturing in

Poland; c) average 2008-2010 data for Ukraine, 2009 data for industrial companies in Poland; d) 2011 data for Ukraine, 2009 data for Poland.

Source: author's calculations on the base of (Boguszewski et al., 2013, p. 42-50; State Statistical Service of Ukraine, 2012, p. 42, 86, 87, 188, 251, 266; Forex Tools: Yearly Average Rates, 2014; National Bank of Ukraine, 2014). 
The overall trend in terms of regional R\&D intensity is that Polish regions reveal much more cohesion than those in Ukraine: the distance between the best and the worst performing regions in Poland constitutes 12 times, whereas in Ukraine - 82 times. Regional cohesion of R\&D expenditure measured in terms of variation coefficient proves this thesis with a 1.08 ratio in Ukraine and 0.66 - in Poland (Table 3). Another side of R\&D financing is revealed through the innovation expenditure per capita (Table 1), which reflects the level of private sector involvement in the innovation process and business as a key player in the regional innovation systems. In this respect a completely different situation is observed in the two countries. A densely populated capital-city region in Poland permanently shows a divergent position in terms of innovation leadership on the background of all other regions, whose positions are quite evenly distributed by this indicator. The closest counterpart Greater Poland - reported almost 10 times less the ratio of Masovian voivodeship. This reflects the overall trend towards investment and innovation hyper-concentration in the European capital cites (European Commission, 2012a, p. 16). At the same time, the city of Kiev in Ukraine, unexpectedly, occupied the third position after Ivano-Frankivsk and Khmelnitskyi regions, which were far from leading positions in terms of R\&D financing, whereas the city of Sevastopol closes the rating. This observation reflects some completely divergent regional trends in public R\&D financing and private innovation expenditure, as well as highly unstable regional innovation dynamics, which create a tricky picture of the 'regional innovation boom' in Ukraine (V. Chuzhykov, A. Chuzhykov and O. Fedirko, 2014, p. 25-29).

Some $4-9 \%$ of all industrial companies in Poland prefer to innovate in cooperation with other business entities, whereas in Ukraine this share is commonly lower
(0.2-5.8\%); the highest levels of innovation cooperation are observed in some Central and Eastern regions of the country (Table 1). In the both countries, however, cooperative linkages are reported by the regions, which are far from being economic leaders within their country. R\&D employment traditionally belongs to the core comparative advantages of the post-soviet states (Table 1). Both in Poland and Ukraine most of the human R\&D potential has been traditionally concentrated in the capital-city regions, with the only peculiarity in Ukraine being Kharkiv region, which due to the historical trajectory occupies the second position after the city of Kiev, being evidently distanced from the rest of Ukrainian regions.

The analysis of the second group of indicators, reflecting the innovation output of regions, starts with the scrutiny of regional shares of sales of innovation products (Table 2). Generally a low level of innovation products is found in the both countries. However, Polish regions enjoy higher results than their Ukrainian counterparts. A complete divergence of public and private innovation strategies, as well as non-innovation orientation of FDI is reflected by the fact that most of the leading industrial regions are in the lower part of the rating, whereas Kiev-city's indicator is only $1 / 3$ of Poltava region's one and $1 / 2$ the indicator of Transcarpathian region. The implementation of product and process innovations is a core parameter of innovative dynamics. Product innovations have direct effect upon market positions of companies, as high quality, uniqueness and diverse range of products improve company's competitiveness. Process innovations are important in terms of cutting costs and optimizing operational performance. Both types of innovations are technological ones - core for the successful development of regional and local innovation systems. 
Table 2 Innovation output indicators of Polish and Ukrainian regions

\begin{tabular}{|c|c|c|c|c|}
\hline Names of regions & $\begin{array}{l}\text { Share of sales } \\
\text { of innovative } \\
\text { products, } \% \text { a) }\end{array}$ & $\begin{array}{c}\text { Share of companies, } \\
\text { introducing innovative } \\
\text { products, } \% \text { b) }\end{array}$ & $\begin{array}{c}\text { Share of industrial } \\
\text { companies, introducing } \\
\text { innovative processes, } \% \text { c) }\end{array}$ & $\begin{array}{c}\text { Patents on } \\
\text { inventions per } \\
\text { min population }{ }^{\mathrm{d})}\end{array}$ \\
\hline ARC (UA) & 1,4 & 4,0 & 7,2 & 14 \\
\hline Cherkasy (UA) & 5,8 & 4,8 & 5,4 & 18 \\
\hline Chernihiv (UA) & 5,6 & 1,3 & 4,7 & 34 \\
\hline Chernivtsi (UA) & 5,0 & 1,4 & 2,9 & 28 \\
\hline Dnipropetrovsk (UA) & 0,6 & 2,1 & 3,6 & 90 \\
\hline Donetsk (UA) & 2,0 & 2,2 & 4,6 & 17 \\
\hline Ivano-Frankivsk (UA) & 3,8 & 1,8 & 6,6 & 23 \\
\hline Kharkiv (UA) & 2,8 & 3,5 & 12,6 & 125 \\
\hline Kherson (UA) & 5,6 & 2,7 & 3,7 & 39 \\
\hline Khmelnytsky (UA) & 1,2 & 1,1 & 11,6 & 29 \\
\hline Kiev city (UA) & 6,3 & 8,4 & 13,6 & 306 \\
\hline Kiev region (UA) & 2,2 & 1,1 & 2,3 & 26 \\
\hline Kirovohrad (UA) & 5,3 & 2,7 & 6,8 & 126 \\
\hline Luhansk (UA) & 6,1 & 1,2 & 7,5 & 11 \\
\hline Lviv (UA) & 1,6 & 2,1 & 5,0 & 52 \\
\hline Mykolaiv (UA) & 5,9 & 1,5 & 5,7 & 21 \\
\hline Odessa (UA) & 1,5 & 0,5 & 6,0 & 41 \\
\hline Poltava (UA) & 17,4 & 1,3 & 1,9 & 67 \\
\hline Rivne (UA) & 0,8 & 0,8 & 5,1 & 0 \\
\hline Sevastopol city (UA) & 4,9 & 2,7 & 2,7 & 102 \\
\hline Sumy (UA) & 10,6 & 4,3 & 5,6 & 40 \\
\hline Ternopil (UA) & 6,6 & 5,2 & 6,1 & 72 \\
\hline Transcarpathian (UA) & 13,2 & 0,9 & 1,7 & 30 \\
\hline Vinnytsia (UA) & 2,1 & 4,0 & 5,0 & 29 \\
\hline Volyn (UA) & 4,9 & 1,8 & 4,9 & 4 \\
\hline Zaporizhia (UA) & 3,2 & 3,6 & 12,8 & 19 \\
\hline Zhytomyr (UA) & 2,7 & 0,3 & 9,0 & 16 \\
\hline Greater Poland (PL) & 8,0 & 6,5 & 15,9 & 31 \\
\hline Kuyavian-Pomeranian (PL) & 13,5 & 6,6 & 8,8 & 26 \\
\hline Lesser Poland (PL) & 10,4 & 7,3 & 18,4 & 43 \\
\hline Łódź (PL) & 6,7 & 6,1 & 11,7 & 45 \\
\hline Lower Silesian (PL) & 6,0 & 7,6 & 14,8 & 59 \\
\hline Lublin (PL) & 7,4 & 7,2 & 17,0 & 18 \\
\hline Lubusz (PL) & 6,1 & 8,0 & 13,9 & 28 \\
\hline Masovian (PL) & 14,8 & 6,6 & 16,0 & 65 \\
\hline Opole (PL) & 5,9 & 9,5 & 13,7 & 33 \\
\hline Podlaskie (PL) & 9,8 & 6,6 & 14,8 & 13 \\
\hline Pomeranian (PL) & 23,4 & 7,0 & 12,1 & 35 \\
\hline Silesian (PL) & 7,1 & 7,9 & 12,9 & 59 \\
\hline Subcarpathian (PL) & 11,0 & 8,6 & 13,5 & 21 \\
\hline Świętokrzyskie (PL) & 6,0 & 6,3 & 12,7 & 29 \\
\hline Warmian-Masurian (PL) & 11,4 & 5,3 & 14,0 & 6 \\
\hline West Pomeranian (PL) & 5,4 & 5,1 & 10,3 & 25 \\
\hline
\end{tabular}

Notes: a) average 2010-2011 data for total industry sales in Ukraine, 2009 data for total net sales in Poland; b) 2011 data for industrial companies in Ukraine, 2009 data for all companies in Poland; c) 2011 data for Ukraine, 2009 data for Poland; d) 2011 data for Ukraine, 2009 data for Poland. 
Source: author's own calculations on the base of (State Statistical Service of Ukraine, 2012, p. 145, 209, 225, 230, 231) and (Boguszewski et al., 2013, p. 42-50).

Analysis of the regional innovation output allows capturing the following trends:

- Process innovations are more popular than product improvements in both countries, as innovation activities of companies are, for the most part, represented by the purchase (mostly imports) of new hardware and equipment, whereas consumer-oriented product innovations are scarce both in absolute and relevant measures;

- Overall business innovation activity is very low in both countries, generally 4-5 times lower as compared to the average EU-15 level;

- The share of innovative companies in Ukraine is higher in developed regions, whereas in Poland no meaningful statistical correlation with the per capita GDP of region has been found (Table 3).

The number of patents on inventions per million population granted by national patent offices of the relevant countries is unexpectedly much higher in Ukraine than in most of the Polish regions (Table 2). Another important notion is that together with numbers from $R \& D$ employment, this indicator is most strongly correlated with per capita GDP of regions in both countries, which reveals common features of the two scientific systems inherited from the socialist past (Table 3).

Recently two major positive trends have been reported for Poland: the increase in business sector innovation expenditures and improving availability of funds in 2008-2012 (Orłowski, 2014), as well as perceived economic effects of innovative activities (employment, export and firm sales growth) (Boguszewski et al., 2013, p. 23).

The analysis of convergence in the regional innovation development (by means of the coefficient of variation) showed a persistent difference between the two count-ries: almost all innovation capacity indicators for the Ukrainian regions (per capita innovation expenditure being the only exception) revealed the level of variation 2-3 times higher than that of the Polish NUTS-2 regions (Table 3).

The abovementioned discrepancy could be explained by the differences in regional and local development policies as well as innovation policies, implemented in the analyzed countries. After EU accession, Poland received an unprecedented amount of financial allocations from the EU Structural Funds and Cohesion Fund, which allowed the Polish government to implement a convergent European model of regional development. Furthermore, programs supporting innovation and entrepreneurship contributed much to the cohesion of regional innovation systems. Although recently in Ukraine the issues of regional and local innovation development became increasingly apprehended by the state (State Agency on Science, Innovations and Informatization of Ukraine established in 2010; State Fund for Regional Development of Ukraine established in 2011) the overall economic conditions were not conducive for rapid regional innovation dynamics, leaving this sphere devoid of real financial and regulatory support, and resulting in further divergence of regional innovation capacity.

Table 3 Analysis of innovation capacity indicators variation and correlation versus per capita GDP of regions in Poland and Ukraine

\begin{tabular}{|l|c|c|c|c|}
\hline \multirow{2}{*}{} & \multicolumn{2}{|c|}{ Ukraine } & \multicolumn{2}{c|}{ Poland } \\
\cline { 2 - 5 } & $\begin{array}{c}\text { Variation } \\
\text { coefficient }\end{array}$ & $\begin{array}{c}\text { Correlation vs. } \\
\text { per capita GDP } \\
\text { of region }\end{array}$ & $\begin{array}{c}\text { Variation } \\
\text { coefficient }\end{array}$ & $\begin{array}{c}\text { Correlation vs. } \\
\text { per capita GDP of } \\
\text { region }\end{array}$ \\
\hline Share of R\&D expen-diture in the GDP of region, \% & 1.08 & 0.57 & 0.66 & 0.67 \\
\hline Per capita innovation expenditure, EUR & 1.00 & 0.27 & 2.17 & 0.67 \\
\hline Share of companies innovating in cooperation, \% & 0.59 & -0.12 & 0.21 & 0.03 \\
\hline R\&D employment per 100 thousand & 1.69 & 0.89 & 0.60 & 0.87 \\
\hline Share of sales of innovative products, \% & 0.80 & 0.04 & 0.48 & 0.24 \\
\hline $\begin{array}{l}\text { Share of companies, introducing innovative } \\
\text { products, \% }\end{array}$ & 0.46 & 0.51 & 0.16 & -0.07 \\
\hline $\begin{array}{l}\text { Share of industrial companies, introducing } \\
\text { innovative processes, \% }\end{array}$ & 0.53 & 0.34 & 0.17 & 0.15 \\
\hline Patents on inventions per mIn population & 1.24 & 0.77 & 0.42 & 0.81 \\
\hline
\end{tabular}

Source: author's own calculations on the base of (Boguszewski et al., 2013, p. 42-50; State Statistical Service of Ukraine, 2012, p. 42, 86, 87, 145, 188, 230, 231, 251, 266; Główny Urząd Statystyczny, 2012) 


\section{Managerial Implications}

A number of implications for adapting business strategies to the weak post-soviet regional innovation systems might be drawn from the research. First, most of regional innovation capacity indicators had low correlation with per capita GDP of a region, both in Poland and Ukraine, disclosing the low level of economic efficiency of innovations, or, better to say, the overall insufficient volumes of innovative activities and lack of critical mass of product and process innovations. The indicators like 'the share of sales of innovative products', 'the share of companies introducing innovative products', 'the share of companies innovating in cooperation', 'the share of industrial companies, introducing innovative (technological) processes' had either low, or even reverse correlation results versus per capita GDP of a region. As for the processes of innovation partnership and collaboration in the post-soviet countries, they are extremely low, reflecting the relevant level of social capital in these states. Companies prefer to innovate in isolation rather than collaborate because of a low level of trust with their business counterparts and high risks of business secrets being leaked.

Secondly, it was found that the interrelations between the R\&D potential (assessed through R\&D expenditures, R\&D employment and patents on inventions) and an overall economic position of a region in Poland and Ukraine (estimated on the base of per capita GDP of a region) were much tighter than the influence of industrial innovation on the regional economic performance. This conclusion can of course be argued based on the notion that commercial outcomes of regional and local innovations are not always exploited in the locality of their origin due to the well-known effects of transnational business strategies. However, in the case of Poland and Ukraine we most likely observe the trace of the socialist heritage connected with the former S\&T governance stereotypes. The allocation of funds in the S\&T sphere was based on the institutional principle, which is a complete antipode of the modern projectbased approach dominating in the EU, which is built on the competition of ideas, research teams, institutions and networks. Finally, the high correlation of regional R\&D potential and economic performance in Poland and Ukraine can't be explained by the logics prevailing in developed countries, where a knowledge based economy constitutes the core object of the state economic policy. Here another explanation seems to be more presumable: the R\&D institutional base was traditionally developed in the capital-city regions (Kyiv, Warsaw, Moscow etc.) as well as in the core industrialized areas (like
Kharkiv, Donetsk and Dnipropetrovsk in Ukraine). In their turn, these regions traditionally were economic and engineering leaders within their states. Thus, it was not the R\&D potential that had always determined the regional economic performance in the post-socialist countries, but on the contrary - the economic status of the region and its significance in the administrative hierarchy had always been a decisive factor for the development of its scientific and technological potential. Nowadays, however, Ukraine is trying to depart from the outdated soviet model of regional innovation policy. A number of recent reforms in the Ukrainian scientific and educational systems might serve as a good evidence thereof (implementation of a competition based approach to the government $\mathrm{R} \& \mathrm{D}$ funding for the universities and research institutions; introduction of universities rating systems, based on international publications and citation indexes, external R\&D financing through grant agreements). The situation in Poland has changed significantly due to the transformations triggered by EU accession. Boguszewski, Czyż, Klimczak, Kowalczyk and Plawgo (2013, p. 23) prove that the goals and the content of regional innovation strategies in Poland are absolutely compatible with the 'Europe 2020' Strategy. Third, a number of developed regions within both countries, which used to benefit from public financial support and localization of R\&D potential, appeared to be incapable of effectively exploiting those virtues. In Ukraine, this is especially evident in the case of old industrial Dnipropetrovsk and Donetsk regions. In Poland, the same conclusion is made in relation to the provinces Łódz, Świętokrzyskie, Silesian, Lesser Poland, Subcarpathian, Greater Poland, Kuyavian-Pomeranian, and Warmian-Masurian voivodeship. According to Boguszewski (2013, p. 41), "the use of the existing mechanisms of innovation potential, including a possible implementation of the RIS system, do not allow for efficient use of their strengths. They are the provinces, whose potential 'input' does not translate to 'output'".

So, the task of constructing coherent innovation systems in the regions is yet to remain urgent for both countries in the foreseeable future because of a number of common constraints for the implementation of an innovationdriven development model (insufficient transfer of knowledge from public sector to business, lack of cooperative linkages and public-private partnerships, lack of technology mediating organizations, lack of domestic business sector innovation expenditure, low access to high risk capital, highly unstable regional dynamics of innovation performance; exhausting brain drain, etc.) 


\section{References}

Asheim, B.T., Lawton-Smith, H., Oughton, C. (2011). Regional Innovation Systems: Theory, Empirics and Policy. Regional Studies, 45 (7): 875-891.

Boguszewski, R., Czyż, P., Klimczak, T., Kowalczyk, A., Plawgo, B. (2013). Regionalne Systemy Innowacjiw Polsce - Raport z Badań, [Regional Systems of Innovation in Poland - Scientific Report]. Warsaw: Wydawnictwo Naukowe Instytutu Technologii Eksploatacji - PIB w Radomiu.

Braczyk H.-J., Cooke P., Heidenreich M. (1998). Regional Innovation Systems: The Role of Governances in a Globalized World. London: UCL Press.

Chuzhykov, V., Chuzhykov, A., Fedirko, O. (2014). Methodological Background of Post-Soviet Regionalism: the Case of Ukraine. Baltic Journal of European Studies, 4 (1): 20-33.

Cooke, P. (1992). Regional Innovation Systems: Competitive Regulation in the New Europe. Geoforum, 23(3): 365-382.

Etzkowitz, H., Leydesdorff, L. (1997). Universities in the Global Economy: A Triple Helix of Government-Industry and Government Relations. London: Croom Helm.

European Commission (2012a). Regional Innovation in the Innovation Union. Luxembourg: Publications Office of the European Union.

European Commission (2012b). Regional innovation scoreboard 2012. Belgium: Publications Office of the European Union.

Forex Tools: Yearly Average Rates, (accessed August 18, 2014), [available at: http://www.bank.gov.ua/files/ Exchange_r.xls].

Freeman, C. (1987). Technology Policy and Economic Performance. London: Pinter.
Główny Urząd Statystyczny (2012). Science and technology in Poland in 2010. Warsaw: Informacjei Opracowania Statystyczne

Koschatzky, K. (2000). The Regionalisation of Innovation Policy in Germany - Theoretical Foundations and Recent Experience. Karlsruhe: Fraunhofer Institute for Systems and Innovation Research (ISI).

Lundvall, B. (1992). National Systems of Innovation: Towards a Theory of Innovation and Interactive Learning. London: Pinter.

National Bank of Ukraine (2014). Oficiiniy Kurs Hryvny shodo inozemnyh valiut (seredniy za period), [Official Exchange Rate of Ukrainian Hryvniya against Foreign Currencies (Annual Averages)], (accessed August 18, 2014), [available at: http://www.ozforex.com.au/ forex-tools/historical-rate-tools/yearly-average-rates].

Nelson, R. (1992). National Innovation Systems: a Retrospective of a Study. Industrial and Corporate Change, 1(2): 347-374.

Orłowski, K. (2012). Poland \& the World, (accessed April 11, 2014), [available at: http://www.pi.gov.pl/eng/ chapter_95512.asp]

State Statistical Service of Ukraine (2012). Naukova ta innovaciina diyalnist $v$ Ukraini, [Scientific and innovation activity in Ukraine], DP 'Informaciinovydavnychyi tsentr Derzhstatu Ukrainy’, Kiev.

Author

Dr. Oleksandr Fedirko

Ph.D., Associate Professor

Deputy Head of the European Integration Department Kyiv National Economic University named after Vadym Hetman

Room 514, Prospekt Peremohy Avenue 54/1, Kyiv, Ukraine, 03680 alexfedirko@yahoo.com 